\title{
Mortality and causes of death in male Croatian Olympic medalists
}

\author{
Vedran Radonić ${ }^{*}$, \\ Damir Kozmar'2, \\ Darko Počanić́, \\ Helena Jerkić², \\ (PIvan Bohaček ${ }^{3}$, \\ Tomislav Letilović
}

IInstitute for Emergency

Medicine Sisak and

Moslavina County, Sisak

Croatia

2University Hospital Merkur,

Zagreb, Croatia

${ }^{3}$ University of Zagreb School of Medicine, University Hospital Centre Zagreb, Zagreb, Croatia
RECEIVED:

July 19, 2017

ACCEPTED:

September 26, 2017

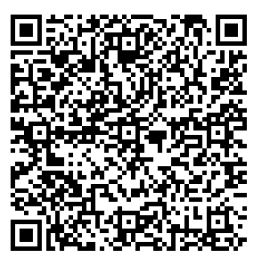

KEYWORDS: athletes, mortality, cause of death, sports.

CITATION: Cardiol Croat. 2017;12(9-10):391. | https://doi.org/10.15836/ccar2017.391

*ADDRESS FOR CORRESPONDENCE: Vedran Radonić, Zavod za hitnu medicinu Sisačko-moslavačke županije. Ulica 1. Svibnja 20, HR-44000 Sisak, Croatia. / Phone: +385-91-7877-085 / E-mail: vedran.radonic91@gmail.com ORCID: Vedran Radonić http://orcid.org/0000-0002-2115-2826 • Damir Kozmar http://orcid.org/0000-0001-7626-3534 Darko Počanić http://orcid.org/0000-0003-3257-110X • Helena Jerkić http://orcid.org/0000-0002-1650-4735 Ivan Bohaček http://orcid.org/0000-0002-1405-2771 • Tomislav Letilović http://orcid.org/0000-0003-1229-7983 IIIIIIIIIIIIIIIIIIIIIIIIIIIIIIIIIIIIIIIIIIIIIIIIIIIIIIIIIIIIIIIIIIIIIIIIIIIIIIIIIIIIIIIIIIIIIIIIIIIIIIIIIIIIIIIIIIII

Aim: To compare the overall and disease-specific mortality of Croatian male athletes who won one or more Olympic medals representing Yugoslavia from 1948 to 1988 or Croatia from 1992 to 2016, and the general Croatian male population standardized by age and time period. While it is well known that regular physical activity improves general health and reduces the risk of premature mortality, effects of vigorous training are still unclear1. Still, a large retrospective multinational study which included 15174 Olympic medalists found that they have lower mortality than their general populations; however, that study did not examine causes of death of the athletes ${ }^{2}$.

Methods: All 233 Croatian male Olympic medalists were included in the study. Information about life duration and the cause of death for the Olympic medalists who died before January 1, 2017, was acquired from their families and acquaintances. For deceased Olympic medalists, medical documentation was requested. Croatian Bureau of Statistics (CBS) provided data about the overall and diseasespecific mortality of the Croatian male population standardized by age and time period. Overall and disease-specific standard mortality ratios (SMR) with 95\% confidence intervals (CI) were calculated to compare the mortality rates of Croatian Olympic medalists and the general population.

Results: Among 233 Olympic medalists, 57 died before the study's endpoint. Cardiovascular diseases were the most common main causes of death (33.3\%), followed by neoplasms (26.3\%) and external causes of death (17.6\%). Overall mortality of the Olympic medalists was found to be significantly lower than that of the general population ( $S M R=0.73, C I=0.56-0.94, p=0.013$ ). Regarding specific causes of death, athletes' mortality from cardiovascular diseases was significantly reduced (SMR=0.61, CI=0.380.93, $\mathrm{p}=0.021$ ) when compared with the general Croatian male population.

Conclusions: Croatian male Olympic medalists benefit from lower overall and cardiovascular mortality rates in comparison to the general Croatian male population.
LITERATURE IIIIIIIIIIIIIIIIIIIIIIIIIIIIIIIIIIIIIIIIIIIIIIIIIIIIIIIIIIIIIIIIIIIIIIIIIIIIIIIIIIIIIIIIIIIIIIIIIII

1. Eckel RH, Jakicic J, Ard J, de Jesus J, Houston Miller N, Hubbard V et al. 2013 AHA/ACC Guideline on Lifestyle Management to Reduce Cardiovascular Risk. J Am Coll Cardiol. 2014;63:2960-84. https://doi.org/10.1016/j.jacc.2013.11.003

2. Clarke PM, Walter SJ, Hayen A, Mallon WJ, Heijmans J, Studdert DM. Survival of the fittest: retrospective cohort study of the longevity of Olympic medallists in the modern era. BMJ. 2012;345:e8308. https://doi.org/10.1136/bmj.e8308 